\title{
O comportamento dos partidos políticos em impeachment presidencial : comparando os casos Fernando Collor de Mello e Dilma Rousseff
}

\author{
Maria do Socorro Sousa Braga \\ professora de Ciência Política, Universidade Federal de São Carlos \\ msbraga@ufscar.br
}

\section{Resumo}

O objetivo deste artigo é verificar o comportamento dos partidos políticos nos dois impeachments presidenciais que ocorreram na vi República brasileira. Para que este mecanismo seja usado nas crises políticas de governança, uma condição necessária é que uma parcela significativa do Legislativo, dois terços no caso da legislação brasileira, vote pela destituição do chefe do Executivo. Mas, se em 1990 o ex-presidente Fernando Collor de Mello de fato não contava com o apoio da maioria dos partidos para governar, em 2015 a ex-presidente Dilma Rousseff começou o seu mandato com ampla coalizão. Argumenta-se que nas duas crises políticas a falta do apoio de um grande partido de centro, garantidor do equilíbrio necessário à governabilidade, reduziu sobremaneira as chances de continuidade desses chefes do Executivo. Entre as principais conclusões, verificou-se que, no caso de Collor a estratégia de se colocar como o herói solitário afastou quase todos os partidos. No caso de Rousseff, embora tenha formado coalizão governamental ampla e heterogênea ideologicamente, incluindo um partido grande de centro, о РМDв, este foi, no entanto, o principal artífice do impeachment.

\section{Palavras-chave}

impeachment - presidencialismo - coalizões governamentais - sistema partidário Brasil 


\section{Le comportement des partis politiques dans la destitution présidentielle : comparer les cas Fernando Collor de Mello et Dilma Rousseff}

\section{Résumé}

L'objectif de cet article est de vérifier le comportement des partis politiques dans les deux destitutions présidentielles qui ont eu lieu dans la vıe République brésilienne. Pour que ce mécanisme puisse être utilisé, une condition importante est qu'une partie importante de la Législative, deux tiers dans le cas de la législation brésilienne, vote pour le renvoi du chef de l'exécutif. Mais si en 1990 l'ancien président Fernando Collor de Mello n'avait pas le soutien de la plupart des partis, l'ancienne présidente Dilma Rousseff a commencé son mandat en 2015 avec une large coalition. On a fait valoir que dans les deux crises politiques, le manque de soutien d'un grand parti du centre, garant de l'équilibre nécessaire à la gouvernabilité, a considérablement réduit les chances de continuité de ces dirigeants. Parmi les principales conclusions, il a été constaté que dans le cas de Collor, la stratégie de poser comme le héros solitaire aliéné presque tous les partis. Dans le cas de Rousseff, bien qu'il ait formé une coalition de gouvernement large et idéologiquement hétérogène, y compris un grand parti du centre, le PMDB, il était, cependant, l'ordonateur principal de la destitution.

\section{Mots-clés}

destitution - présidentialisme - coalitions gouvernementales - système de partis Brésil

\section{The Behavior of Political Parties in Presidential Impeachment: Comparing the Cases of Fernando Collor de Mello and Dilma Rousseff}

\footnotetext{
Abstract

The objective of this article is to verify the behavior of political parties in the two presidential impeachments that occurred in the vi Brazilian Republic. For this mechanism
} 
to be used a necessary condition is that a significant portion of the Legislative, two thirds in the case of Brazilian legislation, vote for the dismissal of the chief executive. But in 1990 former President Fernando Collor de Mello did not actually have the support of most parties to govern, whereas in 2015 former President Dilma Rousseff began her mandate with a broad coalition. It is argued that in both political crises the lack of support from a major center party, guarantor of the necessary balance to governability, greatly reduced the chances of continuity of these chief executives. Among the main conclusions, it was found that in the case of Collor the strategy of posing as the lone hero alienated almost all parties. In Rousseff's case, although she had formed a broad and heterogeneous ideological coalition of government, including a large center party, the PMDB, it was the main architect of impeachment.

\section{Keywords}

impeachment - presidentialism - government coalitions - party system - Brazil

\section{Introdução}

Com menos de trinta anos da promulgação de sua atual Constituição ${ }^{1}$, o Brasil vivenciou dois impeachments presidenciais: o processo de impedimento do ex-presidente Fernando Collor de Mello (PRN), cujo desfecho se deu ao final de 1992, e o da ex-presidente Dilma Rousseff (PT), consumado no fim do primeiro semestre de 2016. Apesar da variável tempo, tendo em vista a brevidade dessa segunda experiência, enfrentamos o desafio neste artigo de investigar a seguinte questão: qual foi o comportamento dos partidos políticos nos dois processos de interrupção dos mandatos presidenciais? De acordo com a literatura especializada sobre crises em sistemas presidencialistas, o impeachment de Collor de Mello foi explicado partindo-se dos seguintes fatores: características pessoais do presidente, o modo como exerceu a Presidência, as disputas político-institucionais, a fragmentação partidária, o desgaste de Fernando Collor junto à opinião pública, a mobilização da sociedade civil, a incapacidade de negociação política do chefe de governo ou, ainda, uma combinação desses aspectos (Sallum Jr e Casarões 2011). Embora ainda não tenha sido objeto de análises mais profundas, o impeachment de Dilma Rousseff parece envolver parte desses aspectos, tendo em vista tratar-se de fenômeno político para o

1 A atual Constituição brasileira foi promulgada no dia 5 de outubro de 1988 e completará 30 anos em 2018. 
qual concorrem múltiplas causas. Para Limongi (2017), o fator primordial passa pela decisão do governo Dilma de não oferecer proteção a boa parte da elite política, incluindo o ex-presidente da Câmara dos Deputados, o peemedebista Eduardo Cunha, e mais 366 parlamentares ameaçados pelas investigações da operação Lava Jato.

Para Pérez-Liñán (2007), quatro condições foram essenciais para o desencadeamento de um processo de impeachment em países da América Latina da terceira onda de democratização, ao menos até 2004: crise econômica, escândalo político, indignação popular e falta de apoio legislativo ${ }^{2}$. No caso dos dois impeachments brasileiros, argumentamos que esse último aspecto foi fundamental. Isso porque, pela legislação brasileira ${ }^{3}$, para que o impedimento ocorra, é condição necessária que dois terços dos parlamentares votem pela destituição do chefe do Executivo. Mas, se em 1992 o ex-presidente Collor de Mello de fato não contava com o apoio da maioria dos partidos para governar, em 2015, no entanto, a ex-presidente Dilma começou o seu mandato com uma ampla coalizão que lhe garantia uma maioria folgada. O governo somente vai começar a perder sua capacidade de atração de apoio da base governamental nos meses que antecederam o processo de impedimento em meio ao acirramento das crises política e econômica.

Quais foram as razões para esse abandono da coalizão governamental pelo PMDB e dos partidos do Centrão ${ }^{4}$ ? Argumentamos aqui, seguindo os principais pressupostos da escolha racional, em sua vertente partidária, que tanto no impeachment de Rousseff quanto no de Collor de Mello, os parlamentares, até então aliados ao governo, tomaram decisões visando sua sobrevivência política, sendo que, no caso de Collor, que já contava com uma minoria parlamentar, a influência das pressões eleitorais e sociais influenciaram as decisões dos parlamentares nesse sentido, enquanto no caso de Rousseff, o fator primordial

2 Pérez-Liñán (2007) analisa o período histórico entre 1992 e 2004, quando seis presidentes latino-americanos enfrentaram processos de impeachment e quatro foram afastados de suas funções. Os casos analisados são Fernando Collor de Mello (Brasil, 1992), Carlos Andrés Pérez (Venezuela, 1993), Ernesto Samper (Colômbia, 1996), Abdalá Bucaram (Equador, 1997), Raúl Cubas Grau (Paraguai, 1999) e Luis González Macchi (Paraguai, 2002).

3 A lei que regulamenta o processo de impeachment no Brasil, definindo os crimes de responsabilidade e que regula o processo de julgamento desses ilícitos, foi editada na Lei n. 1.o79, de 1950.

4 O Centrão é um grupo parlamentar formado por 13 partidos conservadores comandados pelo ex-presidente da Câmara Eduardo Cunha, sendo crucial no impeachment de Rousseff. A origem do termo Centrão é a Constituinte de 1988 e remete à formação de uma maioria capaz de mudar o jogo no Congresso. Durante os debates sobre a nova Constituição, em 1987, um grupo suprapartidário de centro e direita se formou para dar apoio ao então presidente José Sarney. 
foi a perda da capacidade do governo de oferecer alternativas de proteção à maioria da elite política da base de apoio, especialmente à do maior partido de centro de sua coalizão governamental, o PMDB, envolvida em denúncias da operação Lava Jato.

Para explicarmos esse desfecho, no caso de Rousseff, um argumento mais geral está relacionado ao processo de reconfiguração do sistema partidário a partir de 2014, sendo uma das variáveis explicativas da crise política ainda em andamento no Brasil. Supomos que fatores disruptivos endógenos e exógenos vêm produzindo dinâmicas de transformação do sistema partidário, redundando em possível desestabilização dos padrões de competição política em nível nacional e no aumento da fragmentação do poder político.

Para encaminhar esta análise, o texto foi estruturado da seguinte maneira. Na próxima seção verificamos as principais transformações do sistema partidário brasileiro e as relações com o processo governativo. Para isso serão mobilizados os principais aspectos endógenos e exógenos que influenciaram a dinâmica de coordenação e negociação dos atores partidários. Na terceira seção, descrevemos o contexto político no qual foram realizados os dois impeachments, quando será analisada a correlação de forças do sistema partidário eleitoral e parlamentar das duas legislaturas investigadas. Na quarta seção, identificamos e analisamos as principais características dos governos Collor e Rousseff no que diz respeito à composição partidária da coalizão governamental, bem como às relações de integração entre os Poderes Executivo e Legislativo e a proporcionalidade da coalizão legislativa. Verificamos, finalmente, como os partidos da coalizão legislativa se comportaram nas votações que levaram aos impeachments de Collor e Rousseff. Na quinta seção, tecemos as considerações finais. Por se tratar de uma análise exploratória, metodologicamente foram criados indicadores quantitativos para demonstrar nossos argumentos.

Considerações sobre as transformações do sistema partidário brasileiro e as relações com o processo governativo

De acordo com o argumento de Bardi e Mair (2008), sendo os sistemas partidários fenômenos multidimensionais, eles propõem três dimensões para sua análise: a vertical (pilarização); a horizontal (territorial) e a funcional (arenas eleitoral, parlamentar e governamental). Essas divisões funcionais decorreriam da existência de diferentes arenas competitivas, inclusive na mesma esfera de governo. Para os objetivos deste trabalho, iremos privilegiar a dimensão funcional, o que nos permitirá avaliar o comportamento dos atores partidários 
na arena eleitoral (estratégias de coordenação de coligações eleitorais) e nas arenas parlamentar/governamental (coalizões de governo). Isso porque, em alguns sistemas políticos, como o brasileiro, as arenas políticas se caracterizam por regras de competição muito distintas, de tal forma que questões relevantes na arena eleitoral podem não ser na arena parlamentar, e vice-versa. Ademais, outros fatores institucionais podem também ser responsáveis por diferentes condições de competição e cooperação entre os partidos em interação nessas duas arenas. Entre esses aspectos, no caso do sistema político brasileiro, estão o mix de sistemas eleitorais (sistema majoritário de dois turnos para as eleições majoritárias nos três níveis de competição - local, estadual e nacional -, sistema majoritário de turno único para o Senado Federal e o sistema proporcional de lista aberta para as Câmaras Legislativas); a realização de coligações; o próprio sistema federativo; o sistema direto e indireto de financiamento público dos partidos e das campanha eleitorais e a legislação partidária, que institui o monopólio da representação dos partidos políticos e os obriga a se organizar nas três esferas de poder para participar das eleições.

Sendo assim, o sistema partidário brasileiro resulta das interações entre eleições concomitantes, tanto para o nível estadual quanto para o nacional, regidas por princípios diversos. Consequentemente, as eleições majoritárias contribuem para a redução do número de partidos, redundando numa dinâmica bipartidária para a disputa presidencial. No entanto, as eleições proporcionais favorecem a emergência de sistemas pluripartidários, padrão recorrente das eleições para os Legislativos no Brasil 5 .

Após o período de reorganização (1979-1990), tendo já realizado a primeira eleição presidencial, em 1989, e o impeachment do ex-presidente Collor, em 1992, o sistema partidário brasileiro começou a indicar padrões de acomodação de seus principais partidos políticos, resultando na estabilidade política que perduraria até as eleições de 2014. Mais precisamente, com as eleições gerais de 1994 e a vitória da coalizão de centro-direita, encabeçada pelo Partido da Social Democracia Brasileira ${ }^{6}$ (PSDB), reeleita no pleito seguinte (em 1998),

5 As eleições para os Legislativos estaduais e nacional ocorrem de quatro em quatro anos, juntamente com a disputa para a Presidência da República, único colégio nacional, e as disputas pelos executivos estaduais. Dois anos após a realização desses pleitos, ocorrem as eleições para o nível local, quando são escolhidos os prefeitos e vereadores das 5.560 cidades que conformam as cinco regiões geográficas do país.

6 O PSDB foi fundado em 1988 por políticos oriundos do chamado grupo histórico do PMDB, a partir de divergências entre as principais lideranças peemedebistas. Disputas ideológicas, somadas ao pouco espaço conferido a setores peemedebistas mais de esquerda - formados, sobretudo, por políticos paulistas (Marques \& Fleischer 1998) - e à exclusão deste grupo do processo sucessório à presidência da República, em 1989, foram alguns dos elementos importantes para se compreender a sua criação (Kinzo 1993, Roma 2002). 
o sistema partidário nacional passou a apresentar uma dinâmica bipolarizada. $\mathrm{Na}$ oposição, permaneceu a coalizão de centro-esquerda liderada pelo Partido dos Trabalhadores ${ }^{7}$ (PT) até o pleito de 2002, quando assumiu o governo por mais três mandatos consecutivos (2006, 2010, 2014).

Nas outras disputas, até os primeiros anos de 2000, já foi observado que os maiores partidos tenderam a se nacionalizar enquanto os pequenos partidos permaneciam inclinados à regionalização (Braga 2006, 2010). Mas, paulatinamente, as lógicas de competição nos estados passaram a apresentar cada vez mais padrões semelhantes aos identificados em nível nacional, contribuindo para maior estabilidade do sistema. Outra evidência nessa direção foi a diminuição nas taxas de volatilidade eleitoral (Bohn e Paiva 2007). É importante reafirmar, portanto, que uma característica fundamental do sistema partidário brasileiro, observada mais intensamente até o pleito de 2010, foi o aumento da ação coordenada e congruente entre lideranças dos maiores partidos e boa parte dos partidos menores que gravitam em seu entorno, resultando na elevação de um alinhamento relativamente estável do plano nacional com o subnacional. De acordo com Dalton et al. (1984:11), o alinhamento estável de um sistema partidário é caracterizado por um período eleitoral marcado pela "constância nas coligações partidárias e no equilíbrio partidário agregado", inalterados ao longo de uma série de eleições.

Mas, nas últimas duas eleições (a geral de 2014 e as municipais em 2016), alguns elementos endógenos e, outros exógenos, vêm afetando tanto aquele padrão bipartidário de competição nacional entre os partidos territorialmente, quanto o equilíbrio e as lealdades entre eles e o eleitorado nacional, surgindo sinais de um realinhamento parcial. Essa é uma tendência que somente poderemos testar com mais segurança com a realização dos pleitos futuros. Entre os fatores endógenos disruptivos da estabilidade do sistema de partidos estão justamente as rachaduras no formato de competição bipartidária pela Presidência da República, iniciado em 1994, quando о PSDв е о PT passaram a protagonizar essas disputas, atraindo para suas esferas de influência parte expressiva dos demais partidos. As clivagens governismo e oposição-situação nortearam preferências dos atores políticos no que se refere à articulação de

7 O PT se origina no campo da esquerda, em fins dos anos 1970 e início dos anos 1980, nos contextos de abertura democrática e de crescimento das mobilizações sociais, sindicais e operárias na chamada região do $\mathrm{ABC}$ paulista. Inicialmente foi marcado por perspectivas leninistas (partido revolucionário altamente disciplinado) com elementos social-democráticos (partido reformista de massa) (Azevedo 1995). Organizacionalmente, o partido é composto mais recentemente por diversas tendências com posicionamentos políticos diversos - uns mais à esquerda e outros mais ao centro do espectro ideológico (Ribeiro 2008, Meneguello e Amaral, 2008, Amaral 2010). 
coligações eleitorais e coalizões governamentais e, consequentemente, à distribuição de incentivos e recursos oriundos tanto do Estado quanto do mercado. Já entre os fatores exógenos, um elemento fundamental diz respeito à perda cada vez maior de apoio eleitoral aos partidos em geral, e aos maiores partidos, em particular, produzindo, no pleito de 2014, a Câmara dos Deputados mais fragmentada do período analisado. Conforme classificação de Braga ${ }^{8}$ (2016:50), se, em 1982 ainda predominou o bipartidarismo compulsório imposto durante o regime civil-militar (1964-1985), com o Partido Democrático Social (PDS) governista e o Partido do Movimento Democrático Brasileiro (РMDB), agregando as forças de oposição, ambos mantendo-se como os maiores partidos, de 1986 até 1994, о PMD в е о Partido da Frente Liberal $^{9}$ (PFL) ocuparam essa posição. Em 1998, contudo, três partidos fazem parte dessa categoria (Democratas ${ }^{10}$ DEM -, PSDB е PMDB). Com a alternância de grupo político na Presidência da República nas eleições de 2002, voltamos a ter dois grandes partidos no controle da Câmara: PT e DEM. No pleito seguinte, em 2006, о РMD в е o PT ocuparam essa posição e, em 2010, apenas o PT se manteve nessa categoria. Já em 2014, o sistema partidário parlamentar não apresenta mais partido grande, tendo o PT, PSD в е РMDB passado à categoria de partidos médios, enquanto o DEM caiu para a categoria de partido pequeno. Mas a categoria que teve o maior aumento foi a dos micropartidos, passando de 7, em 2010, para 12 micropartidos com representação na Câmara, em 2014, redundando em 28 partidos com cadeiras naquela Casa.

Outro fator disruptivo exógeno ao sistema partidário está relacionado com a operação Lava Jato conduzida pela Polícia Federal e o Ministério Público

8 Segundo essa classificação, partidos grandes são aqueles que possuem acima de 81 (ou 16\%) das cadeiras na Câmara; enquanto os partidos médios são considerados aqueles que detêm de 31 a 80 (ou $6 \%$ a $15 \%)$ cadeiras. Os pequenos partidos possuem de 10 a $30(2 \%$ a $6 \%$ ) das cadeiras e os micropartidos têm menos de 10 (menos de $2 \%$ ) assentos.

9 Fundado oficialmente em janeiro de 1985, o PFL tem sua origem vinculada à crise provocada no PDs durante o processo de escolha do candidato oficial à sucessão do presidente general Figueiredo (Kinzo 1993: 45).

10 O PFL se rebatizou como Democratas (DEM) em 2007, evidenciando preocupações com a evolução declinante da sigla no quadro partidário nacional. Essa refundação teve como marca também uma sucessão geracional no partido, consolidada com a derrota do carlismo na Bahia, tradicional reduto pefelista, bem como com a ascensão de novos quadros. Carlismo é o termo utilizado para designar o grupo formado no estado brasileiro da Bahia em torno da liderança de Antônio Carlos Magalhães (1927-2007), que durante quatro décadas foi o político mais importante do estado e um dos mais influentes do Brasil. Após anos na presidência do PFL, Jorge Bornhausen foi sucedido na presidência da nova legenda pelo deputado federal fluminense Rodrigo Maia, trinta anos mais jovem e filho do ex-prefeito do Rio de Janeiro, César Maia (Braga 2016b, http://www.fgv.br/cpdoc/acervo/ dicionarios/verbete-tematico/democratas-DEM). 
Federal, iniciada em março de 2014 e, ainda, em andamento. A revelação do esquema de corrupção na Petrobras, nas maiores empresas de construção do país (Odebrecht, OEA, Camargo Correia, Andrade Gutierrez, entre outras) e, posteriormente, em empresas de proteína animal (J\&F e JBS) envolvendo vários quadros da elite política brasileira, boa parte vinculada à base de sustentação dos governos petistas, contribuiu para deteriorar ainda mais a avaliação negativa de parte considerável da opinião pública sobre os partidos políticos e o governo federal, aumentando os índices de apartidarismo identificados nas manifestações de 2013 no país.

Argumentamos que todos esses fatores disruptivos vêm afetando o sistema partidário e a atuação dos partidos na arena governativa e que, no pleito de 2016, mais evidências surgiram no sentido de termos uma das eleições mais críticas de toda a história democrática recente, redundando no início do realinhamento parcial das forças políticas. Embora o desempenho dos partidos no pleito nacional de 2014 já indique o sentido dessas mudanças, o pleito municipal de 2016 confirmou tanto a substituição dos vínculos constituídos entre partidos relevantes, como o PT, e o eleitorado, quanto as alterações nas próprias percepções do eleitorado e, ainda, as mudanças nas estratégias competitivas das elites políticas.

\section{Da disputa eleitoral a governos com partido presidencial sem maioria: a correlação de forças políticas em Collor e Rousseff}

Os dois casos de impeachment no Brasil ocorreram em contextos políticos eleitorais singulares. Em fins dos anos 1980 deu-se a primeira eleição direta para a Presidência da República após mais de vinte anos ${ }^{11}$ de autoritarismo. Depois de tanto tempo sem escolher o chefe do governo, a disputa pelo cargo mais importante da sexta República brasileira contou com alto número de candidatos e de participação popular. Foram 21 partido ${ }^{12}$, que juntos conseguiram 66.156.191 votos, representando $93,5 \%$ dos votos válidos. $\mathrm{O}$ comparecimento às urnas

11 Durante o regime civil-militar (1964-1985) todos os presidentes foram indicados e, em 1985, um colégio eleitoral escolheu indiretamente o primeiro presidente civil (Kinzo 1993).

12 Entre os setores progressistas concorreram Leonel Brizola, pelo PDT, Mário Covas, pelo PSDB, Roberto Freire, pelo РСв е, pelo centro, Ulisses Guimarães, pelo РMDB; enquanto pelos setores conservadores, que apoiaram as forças ligadas ao regime militar, estavam Paulo Maluf, do PDS, Aureliano Chaves, do PFL, Guilherme Afif Domingos, do PL, Ronaldo Caiado, do PSD, Affonso Camargo, do РTв e mais 10 pequenos partidos (Nicolau 1998). 
chegou a $88 \%$ do eleitorado nacional. Foram para o segundo turno o ex-governador do estado de Alagoas, Fernando Collor de Mello, do pequeno Partido da Reconstrução Nacional (PRN), que em coligação com outros dois partidos inexpressivos (PST, PSL) obteve 30,5\% dos votos, e o ex-deputado federal pelo estado de São Paulo e sindicalista, Luís Inácio Lula da Silva, do Partido dos Trabalhadores (PT), que em coligação com o PSB e PCdoB conseguiu 17,2\%. No segundo turno, as forças políticas se reposicionaram, enquanto parte dos partidos progressistas apoiou o candidato petista, partidos conservadores buscaram se aproximar do candidato do PRN. É importante salientar que, desde o início de sua campanha eleitoral, Collor de Mello buscou construir sua candidatura rejeitando compromissos com políticos, partidos e diversos grupos de interesse, colocando-se como o político "novo" que iria salvar o país dos seus problemas econômicos, sociais e da corrupção. Este seu posicionamento isolacionista acabaria afetando a formação do seu governo e o próprio processo político que levou ao impeachment.

No segundo turno, Collor de Melo venceria com $53 \%$ dos votos, contra $47 \%$ de Lula da Silva ${ }^{13}$. Em torno de Lula uniram-se o PSDB, о PMDB, о Partido Democrático Trabalhista (PDT), o Partido Comunista Brasileiro e pequenos partidos de esquerda, além da Central Única dos Trabalhadores (CUT). Collor recebeu o apoio da Federação das Indústrias do Estado de São Paulo (FIESP), que oficialmente recusou, da Confederação das Associações Comerciais do Brasil e da Confederação Geral dos Trabalhadores (CGT).

Para entendermos como estava a distribuição do poder partidário durante o governo Collor é importante considerar que o Congresso ${ }^{14}$, as Assembleias Estaduais e os governos estaduais dos 27 estados seriam eleitos um ano após a realização do pleito presidencial. Nas eleições de 1990, os aliados do presidente Collor de Mello venceram no Distrito Federal e na maioria dos estados, com destaque para o $\mathrm{PFL}$, que elegeu nove governadores, seis dos quais na região de origem do presidente, o Nordeste. Tal desempenho compensou, ao menos em parte, as derrotas sofridas em grandes colégios eleitorais, como São Paulo, Rio de Janeiro e Rio Grande do Sul. Já o partido do presidente, o PRN, elegeu dois senadores e quarenta deputados federais e não fez nenhum governador. Com esse resultado, o ex-presidente teria necessariamente que compor uma coalizão para governar. Mas, como veremos mais à frente, poucos foram os partidos

13 Fernando Collor de Mello venceu em 22 das 27 unidades da federação e teve mais de $50 \%$ dos votos em 18 destes Estados, incluindo São Paulo, o estado mais desenvolvido economicamente do país (Nicolau 1998).

14 Congresso brasileiro formado pela Câmara dos Deputados, com 503 cadeiras, e o Senado, com 81. Em 1990 escolheria 1/3 das cadeiras, totalizando 31 cadeiras (Nicolau 1998). 
que aderiram ao seu governo, conformando coalizões ad doc. No legislativo, o PMDB manteve a maior bancada tanto na Câmara dos Deputados quanto no Senado Federal e, com isso, conservou o comando do congresso para o biênio seguinte. Ao longo daquela legislatura, liderou uma forte oposição ao governo em votações-chaves do Plano Collor ${ }^{15}$.

Já a ex-presidente Dilma Rousseff foi reeleita, nas eleições de 2014, em meio a forte crise política e econômica. É importante ressaltar que se tratava do terceiro mandato do $\mathrm{PT}$ à frente do comando do país. A tabela 1 revela o desgaste dos petistas, que, além de vencerem a eleição presidencial por margem de votos muito apertada, elegeu as menores bancadas para o Congresso desde que chegou ao Planalto, em 2002.

TABEla 1 Desempenho para a Presidência, Câmara dos Deputados e Senado Federal (2014)

\begin{tabular}{|c|c|c|c|c|c|c|}
\hline \multirow{2}{*}{ Partidos } & \multicolumn{2}{|c|}{ Eleições Presidenciais } & \multicolumn{2}{|c|}{ Câmara } & \multicolumn{2}{|c|}{ Senado } \\
\hline & $\begin{array}{l}\text { Em milhões/ } \\
\text { votos }\end{array}$ & $\%$ & $\mathrm{Nc}$ & $\%$ & $\mathrm{Nc}$ & $\%$ \\
\hline PT & 43.26 & 41,6 & 70 & 13,6 & 3 & 11,1 \\
\hline PMDB & $\mathrm{SCP}^{*}$ & & 66 & 12,9 & 4 & 14,8 \\
\hline PSDB & 34.89 & 33,6 & 54 & 10,5 & 4 & 14,8 \\
\hline $\mathrm{PDS} / \mathrm{PPR} / \mathrm{PPB} / \mathrm{PP}$ & $\mathrm{SCP}^{*}$ & & 36 & 7,4 & 1 & 3,7 \\
\hline PSD & $\mathrm{SCP}^{*}$ & & 37 & 7 & 2 & 7,4 \\
\hline PSB & 22.17 & 21,32 & 34 & 6,7 & 3 & 11,1 \\
\hline $\mathrm{PL} / \mathrm{PR}$ & $\mathrm{SCP}^{*}$ & & 34 & 6,7 & 1 & 3,7 \\
\hline РТВ & $\mathrm{SCP}^{*}$ & & 25 & 5 & 2 & 7,4 \\
\hline $\mathrm{PFL} / \mathrm{DEM}$ & $\mathrm{SCP}^{*}$ & & 22 & 4,1 & 3 & 11,1 \\
\hline PRB & 446 & 0,4 & 21 & 4,1 & & \\
\hline PDT & $\mathrm{SCP}^{*}$ & & 19 & 3,7 & 4 & 14,8 \\
\hline SD & $\mathrm{SCP}^{*}$ & & 15 & 3 & & \\
\hline PSC & 780 & 0,75 & 12 & 2,5 & & \\
\hline РСВ/PPS & 478 & 0,1 & 10 & 2 & & \\
\hline PC do B & $\mathrm{SCP}^{*}$ & & 10 & 2 & & \\
\hline PROS & $\mathrm{SCP}^{*}$ & & 11 & 2,1 & & \\
\hline PV & 630 & 0,6 & 8 & 1,6 & & \\
\hline PSOL & 1.612 & 1,6 & 5 & 1 & & \\
\hline
\end{tabular}

15 Para a atuação do РMDв em relação ao Plano Collor, ver Figueiredo e Limongi (1999: 184-191). 
tabela 1 Desempenho para a Presidência, Câmara dos Deputados e Senado Federal (cont.)

\begin{tabular}{|c|c|c|c|c|c|c|}
\hline \multirow{2}{*}{ Partidos } & \multicolumn{2}{|c|}{ Eleições Presidenciais } & \multicolumn{2}{|c|}{ Câmara } & \multicolumn{2}{|c|}{ Senado } \\
\hline & $\begin{array}{l}\text { Em milhões/ } \\
\text { votos }\end{array}$ & $\%$ & $\mathrm{Nc}$ & $\%$ & $\mathrm{Nc}$ & $\%$ \\
\hline PHS & $\mathrm{SCP}^{*}$ & & 5 & 1 & & \\
\hline PTN & $\mathrm{SCP}^{*}$ & & 4 & 1 & & \\
\hline PSL & $\mathrm{SCP}^{*}$ & & 1 & 0,2 & & \\
\hline PMN & $\mathrm{SCP}^{*}$ & & 3 & o,6 & & \\
\hline PRP & $\mathrm{SCP}^{*}$ & & 3 & 0,6 & & \\
\hline PSDC & 612 & 0,1 & 2 & 0,4 & & \\
\hline PRN/PTC & $\mathrm{SCP}^{*}$ & & 2 & 0,4 & & \\
\hline PTdoB & 123 & & 1 & 0,2 & & \\
\hline PEN & $\mathrm{SCP}^{*}$ & & 2 & 0,4 & & \\
\hline PRTB & 446 & 0,4 & 1 & 0,2 & & \\
\hline PSTU & 912 & 0,1 & & & & \\
\hline $\mathrm{PCO}$ & 123 & 0,1 & & & & \\
\hline Total & 104.023 .802 & 100.0 & 513 & 100.0 & 27 & 100.0 \\
\hline
\end{tabular}

Fonte: Tribunal Superior Eleitoral (TSE), 2014.

${ }^{*} \mathrm{SCP}$ (Sem candidato próprio à disputa presidencial), mas podem ter aderido a coligações partidárias para a Presidência.

**sCS (Sem candidato próprio ao Senado Federal).

Nc (número de cadeiras)

Como podemos verificar, 13 partidos políticos apresentaram candidatos para a sétima disputa presidencial. Entre os 3 partidos relevantes nessa competição, o PT e a coligação de centro-esquerda (PMDB, PSD, PP, PR, PROS, PDT, PCdoB, $\mathrm{PRB}^{16}$ ) obtiveram o maior número de votos no primeiro turno, quase $42 \%$, indo para o segundo turno e vencendo pela quarta vez consecutiva, agora com uma chapa com о Рм Dв, tendo o deputado federal Michel Temer, como vice. A presidente Dilma Rousseff foi reeleita com $51,6 \%$ dos votos válidos, a vitória

16 Esses são os nomes dos respectivos partidos: Partido Social Democrático (PSD), Partido Progressista (PP), Partido da República (PR), Partido Republicano Brasileiro (PRB), situados mais à direita do campo político; Partido Republicano da Ordem Social (PROs), voltado para o Centro; e o Partido Comunista do Brasil (PCdoB), vinculado ao setor da esquerda brasileira (TSE). 
mais apertada dos petistas. Já a segunda maior força, o PSDB e a coligação de centro direita (DEM, PTB, PMN, SD, PEN, PTN, PTC, PTdoB ${ }^{17}$ ), com o candidato Aécio Neves (PSDB-MG), alcançaram quase $34 \%$ dos votos no primeiro turno e $48,4 \%$, no segundo turno.

A terceira força na disputa presidencial, o Partido Socialista Brasileiro (PSB) e a coligação formada por partidos pequenos de diferentes campos ideológi$\cos$ (PHS, PRP, PPS, PPL, PSL ${ }^{18}$ ), tendo como cabeça de chapa a ex-Ministra do Meio Ambiente e ex-petista, Marina Silva ${ }^{19}$, obteve um pouco mais de $21 \%$ dos votos nacionais, redundando no melhor desempenho eleitoral de uma terceira via no Brasil desde então. Seguramente, um dos fatores que afetaram essa eleição foi a morte em acidente de avião do ex-governador de Pernambuco do PSB, Eduardo Campos, então à frente dessa coligação, ainda durante a campanha eleitoral ${ }^{20}$. E, pela primeira vez, desde o pleito de 1994, quando a disputa presidencial se polarizou entre PT e PSDB, tivemos uma terceira alternativa que ameaçou a continuidade desse bipartidarismo semanas antes da realização do primeiro turno. No segundo turno, o apoio de Marina Silva e de boa parte do PSB, além de outros candidatos de partidos menores, ajudaram a fortalecer a candidatura peessedebista, reduzindo a diferença de votos entre PT е PSDB.

No que diz respeito à distribuição do poder nas Casas Legislativas, verificou-se a mais alta fragmentação partidária, quando 28 partidos conseguiram representação na Câmara dos Deputados. Embora os partidos à frente do Executivo, PT e PMDB, continuassem com as maiores bancadas na Câmara

17 Já a coligação de centro-direita era formada pelo Democratas (DEM), Partido Trabalhista Brasileiro (Ртв), o Solidariedade (SD), Partido da Mobilização Nacional (PMN), Partido Ecológico Nacional (PEN), Partido Trabalhista Nacional (PTN), Partido Trabalhista Cristão (PTC), Partido Trabalhista do Brasil (PTdoB) (TSE).

18 Coligação formada pelos pequenos partidos: Partido Humanista da Solidariedade (PHS), Partido Republicano Progressista, Partido Popular Socialista (PPS), Partido da Pátria Livre (PPL), Partido Social Liberal (PSL) (TSE).

19 A candidatura da presidenciável Marina Silva inicialmente tentou se lançar pela Rede, seu partido na época em gestação. Mas como não conseguiu o número suficiente de assinaturas para a criação da Rede, aceitou integrar a coligação eleitoral como a vicepresidenciável de Eduardo Campos, pelo PSB (Braga 2016a).

20 O Candidato presidencial Eduardo Campos, herdeiro do capital político do avô Miguel Arraes (1916-2005), governador de Pernambuco por três mandatos, foi vítima de acidente aéreo quando seguia para cumprir agenda de campanha há dois meses do pleito. O presidenciável acumulou extensa trajetória: foi deputado federal, ministro e governador de Pernambuco por dois mandatos (2007 a 2013). Tornou-se um dos principais articuladores do primeiro governo Lula da Silva (2003-2006), ajudando a mobilizar a base governista para aprovar a Reforma da Previdência. Assumiu, em 2004, o Ministério da Ciência e Tecnologia. No ano seguinte, aceitou a presidência nacional do PSB depois da morte de seu avô. Era filho da deputada Ana Arraes e do poeta Maximiano Campos (Braga 2016a). 
dos Deputados e no Senado Federal, eles perderam cadeiras nas duas Casas em relação ao total de eleitos em 2010, obtendo juntos apenas $24,5 \%$ das cadeiras da Câmara. Diante deste cenário, como veremos adiante, o Executivo necessariamente tinha que recorrer à coalizão governamental para governar. A coligação eleitoral, juntando partidos de amplo espectro ideológico, que reelegeu a presidente Dilma Rousseff, conseguiu 304 das 513 cadeiras da Câmara dos Deputados, garantindo ao governo, ao menos em tese, sustentação política para aprovar proposições e medidas encaminhadas àquela Casa Legislativa.

Em termos contextuais mais gerais cabe ressaltar outros aspectos da dinâmica política-eleitoral que influenciaram o comportamento dos partidos a favor do impeachment da presidente. Essas eleições marcariam importante ponto de inflexão na estabilidade dos principais partidos que estruturavam o sistema partidário brasileiro desde 1994, conforme vimos acima. Isso porque a crise política, iniciada ainda no primeiro mandato da ex-presidente Dilma Rousseff (2010-2014), quando ocorreram amplas manifestações populares contra e favor do governo a partir de 2013, acirrar-se-ia com a operação Lava Jato ao envolver grande parte da elite política.

A crise política foi também agravada pela tentativa da oposição liderada pelo PSDB, de não aceitar o resultado da eleição presidencial de 2014, alargando a instabilidade política. Diante da derrota por pouco mais de $3 \%$ dos votos, o candidato peessedebista, o senador Aécio Neves (PSDB-MG), além de permanecer em estado de campanha permanente, entrou com pedidos de verificação do resultado das eleições no TSE, ameaçando ainda mais a estabilidade política dos últimos anos. Esse clima de desconfiança institucional também acabou incentivando a reação da sociedade civil, levando para as ruas movimentos pró-governo e contrários, expressando a polarização popular que perduraria até a saída da presidente do governo.

Por fim, é importante levarmos em conta que o terceiro governo petista começou com a ex-presidente Dilma isolada, seja por parte de sua própria base de apoio legislativa, que resolveu apoiar a candidatura de Eduardo Cunha para a presidência da Câmara, em fevereiro de $2015^{21}$, seja pelo seu próprio vicepresidente Michel Temer, que paulatinamente passaria a fiador da articulação com o próprio Cunha, o Centrão e a oposição encabeçada pelo PSDB, que levaria ao impedimento da presidente Dilma e, mais adiante, o próprio governo de

21 O deputado Eduardo Cunha (РMDB-RJ) venceu no primeiro turno o candidato do PT, Arlindo Chinaglia (SP), elegendo-se presidente da Câmara dos Deputados com 267 votos, contra 136 do petista. O deputado Júlio Delgado (PSB-MG), que disputou pela oposição (PSDB/PPS/PV), teve 100 votos. Dados retirados de O Globo (Braga, Lima e Gama 2015) no dia $24 / 09 / 2017$. 
transição. É importante salientar que, com o comando das Casas congressuais nas mãos de peemedebistas, e sendo o Eduardo Cunha uma dessas lideranças, desafeto da ex-presidente Dilma Rousseff, com quem sempre teve uma relação difícil no primeiro mandato, quando comandou embates emblemáticos contra o governo, como a aprovação da Projeto de Emenda Constitucional (PEC) que acabou com a Contribuição Provisória sobre Movimentação Financeira (CPMF), as Medidas Provisórias dos portos e do Marco Civil da Internet, conformava-se um РмDв muito fortalecido. Em outras palavras, foi conseguindo ficar cada vez mais independente do Planalto, tornando-se um dos seus principais inimigos no Legislativo com a votação das chamadas agendas "bombas", por gerar mais despesas públicas em um momento de ajuste fiscal.

Essas foram as condições que levaram às dificuldades de Rousseff para passar os impopulares ajustes fiscais, quando foi acumulando altos níveis de desaprovação popular com o agravamento dos indicadores econômicos ao longo daquele ano. Aos poucos, políticas voltadas para a redução da pobreza, a mobilidade social e o desenvolvimento econômico do Brasil foram enfrentando obstáculos, como a recessão, a inflação e o desequilíbrio fiscal. Assim, se durante a campanha eleitoral de 2014, uma parcela do eleitorado ainda não tinha associado o governo aos problemas econômicos que começaram a aparecer mais fortemente com o acirramento da crise econômica no ambiente interno, entre os quais o aumento do desemprego, com a nomeação do ministro Joaquim Levy para o Ministério da Fazenda, adepto do receituário liberal, indicando a mudança de rumo do governo, a decepção tomou conta de parcela considerável do eleitorado mais próximo do campo petista, que passou a criticar os ajustes fiscais, tidos como inevitáveis pelo governo. Configurou-se, assim, uma conjuntura marcada pela progressiva perda de credibilidade da expresidente e do PT, reforçada pela avaliação de setores políticos da oposição e da economia, bem como da mídia nacional, de sua incapacidade de liderança e traquejo político com o Legislativo.

Conforme vimos até aqui, os dois processos de impeachment presidenciais brasileiros foram realizados em contextos cujos presidentes foram eleitos no segundo turno com maiorias relativamente próximas de votos dos seus concorrentes, com seus partidos com bancadas minoritárias nas Casas Congressuais, mas com coligações eleitorais muito diferentes quanto ao número de cadeiras eleitas na arena parlamentar e, também, quanto ao poder desses partidos na eleição dos próprios presidentes. Deve-se mencionar ainda os vínculos de lealdade dessas lideranças partidárias com os respectivos líderes do Executivo, bem como quanto a questões programáticas que deveriam nortear as ações governamentais futuras. No caso do ex-presidente Collor de Mello, este foi eleito em meio a forte desgaste político das principais forças partidárias da chamada 
Nova República. O próprio governo Sarney apresentava altos índices de impopularidade, buscou se manter distante da maioria dos partidos desde o início de sua campanha eleitoral e, mesmo, como veremos a seguir, ao longo dos dois primeiros anos de seu governo. Já a ex-presidente Dilma Rousseff, buscando a reeleição em contexto de grave crise de credibilidade da elite política, incluindo seu próprio partido e a maioria da base do seu governo, realizou ampla coligação eleitoral, incluindo partidos da direita, centro e esquerda sem um compromisso programático. E, como veremos, sua coalizão Legislativa envolveu mais partidos, ampliando sua maioria no Congresso.

Formação de Coalizões Governamentais e Legislativas: composição e proporcionalidade partidária nos governos Collor e Rousseff

Um fator fundamental nas relações entre Executivo e Legislativo num sistema presidencialista multipartidário é a habilidade do presidente na formação de maiorias que respaldem suas ações. Ou seja, num contexto de alta fragmentação partidária como o brasileiro, onde predominam presidentes com partido minoritário no Congresso, a formação de coalizões governamentais e legislativas tornou-se crucial para a eficácia político-operacional desse sistema (Abranches 1988, Figueiredo 2012). Nesse sentido, um outro aspecto importante para avaliarmos a formação dos governos aqui comparados é o de que a formação de coalizões legislativas resulta de negociações ad hoc, enquanto coalizões governamentais envolvem o acesso a cargos e posições de poder em troca de apoio legislativo (Müller e Strom 2000: 12). Quanto mais eficiente o governante for nessas transações, mais duradouro e seguro será o apoio partidário.

Os objetivos desta seção são dois: primeiro, identificarmos e analisarmos as principais características da formação dos governos de Collor e Rousseff visando aumentar o seu apoio na legislatura; segundo, verificarmos o comportamento dos atores partidários da base de apoio governamental ao longo dos dois processos de impeachments.

Argumentamos que no caso do ex-presidente Fernando Collor, os partidos, ao serem negligenciados da articulação política do seu governo, tanto no que se refere à composição do Ministério quanto na formação de uma base de apoio no Congresso, foram fundamentais para a ocorrência deste desfecho. Já no caso da ex-presidente Dilma, seu segundo governo buscou ter maior equilíbrio dos partidos da coalizão na distribuição das pastas ministeriais, alcançando uma base de apoio majoritária. Contudo, a coordenação dessa coalizão governamental, caracterizada por uma maioria partidária ideologicamente muito heterogênea e fragmentada e, especialmente, com forte influência de 
lideranças fisiológicas do PM DB, com grande parte desses políticos ameaçados por denúncias de corrupção pela operação Lava Jato, e, ainda, com a própria tendência majoritária do partido da presidente, insatisfeita com a sua participação diminuída na composição do seu ministério, foi seriamente prejudicada por todos esses fatores. Para testar nosso argumento, primeiro analisamos a composição partidária do Ministério de cada presidente. Em seguida, verificamos qual era a representação dos partidos da coalizão na base de apoio do Executivo no Legislativo. Por fim, identificamos quais partidos da base governamental votaram pelo impeachment dos ex-presidentes. Para a metodologia, utilizamos o método de estatística descritiva para apresentar e analisar os resultados referentes à montagem e operacionalização das coalizões, bem como o voto dos parlamentares nas diferentes etapas desses impedimentos.

\subsection{A representação dos partidos nos Ministérios de Collor e Rousseff}

Observando-se a composição dos Ministérios como indicador da distribuição de poder existente entre os respectivos chefes do Executivo e os partidos políticos que faziam parte da coalizão governamental, verificamos as seguintes características. Primeiro, quanto à formação da equipe ministerial, Collor de Mello, visando dar conta das metas divulgadas ao longo da campanha eleitoral, coordenou um Ministério de perfil mais técnico, menos dependente de partidos e que reduzisse os custos. Para atingir esses objetivos reduziu os 23 ministérios existentes no governo Sarney (1986-1990) para 12, mas criou mais seis secretarias vinculadas à Presidência (Sallum Jr. 2015: 83). Já no que diz respeito ao segundo aspecto, mais importante para este trabalho, Collor manteve sua promessa de campanha de afastar os partidos do seu governo não chamando-os para negociações visando o preenchimento dos cargos. $\mathrm{O}$ resultado dessa estratégia foi que, em média, mais de $60 \%$ dos seus ministros não tinham filiação partidária nenhuma. Mais precisamente, o seu governo, inicialmente, foi formado por poucos políticos do PRN e PFL. Ao seu lado também se manteria o antigo aliado, o deputado Renan Calheiros (PRN-AL), designado líder do governo na Câmara dos Deputados. Em 1991, outros políticos do PDS foram incorporados ao seu Ministério e, em 1992, quando a crise política atingiu grandes proporções, buscou mudar sua estratégia, acrescentando outros quadros políticos do Ртв е PL, aumentando, assim, a presença partidária conservadora no seu ministério 22 . Na oposição estavam os partidos da esquerda (PT, PSB, PCdoB, PCB, PDT) e de centro (PSDB, PMDB).

22 Em 1992, Collor de Mello tentou mudar esse padrão de relacionamento com os partidos quando realizou duas reformas em sua equipe: uma em abril e outra às vésperas de seu 
Por conta dessa escassa participação dos partidos, há importante controvérsia na literatura especializada acerca de sua inclusão entre os exemplos de Governo de coalizão (Amorim Neto 2003, Figueiredo e Limongi 1999). Defendemos que foi justamente esse tipo de estratégia de condução da participação dos partidos em seu governo, negligenciando o modelo de funcionamento do presidencialismo praticado no Brasil, marcado pela fragmentação partidária, e que tem como um dos seus pressupostos de funcionamento a necessidade de o partido do governante eleito, por não contar com uma maioria no Legislativo, ter que abrir espaços no seu Ministério para estruturar uma coalizão governamental, que levou ao seu impeachment.

Outra consequência da alta fragmentação partidária do sistema partidário brasileiro, especialmente das últimas três décadas, foi levar os governantes a criar novos ministérios ao longo da legislatura, seja para abrigar mais legendas para ampliar seu apoio no Legislativo, seja para aumentar o espaço de poder de partidos da própria base do governo. Esse foi o caso do Governo de Dilma Rousseff.

No caso da ex-presidente Dilma, seu segundo governo (2015-2016) buscou promover maior equilíbrio dos partidos da coalizão na distribuição das pastas ministeriais, alcançando uma base de apoio majoritária, tendo em vista que o seu partido, o PT, reduziu ainda mais sua representação na Câmara dos Deputados e sua reeleição dependeu de uma margem de voto mais apertada. Parte dessa estratégia decorreu dos problemas enfrentados pela petista no primeiro governo, quando, apesar de contar com uma coalizão majoritária composta por dez partidos, reunindo cerca de 340 deputados e 52 senadores, enfrentou fases de instabilidade na coalizão, marcada por traições e mesmo derrotas nas votações ${ }^{23}$.

Contudo, conforme informações da tabela 2, a ex-presidente assumiu o segundo governo com um Ministério com as seguintes características: aumentou o número de Ministérios, reduzindo a quantidade de ministros sem filiação partidária; ampliou o número de partidos; ideologicamente se manteve com coalizão heterogênea, mas reduziu a concentração de poder no $\mathrm{PT}^{24}$. Com

afastamento, quando ampliou o espaço aos quadros políticos conservadores (Figueiredo 2007).

23 Como exemplo, vale citar a lei que dividiu royalties do petróleo entre união, estados e municípios, em que foi aprovado projeto que contrariava o governo - o veto de Dilma foi posteriormente derrubado no Congresso.

24 No contexto latino-americano, Altman (2000) desenvolveu um dos primeiros estudos sobre o caso uruguaio onde verificou que a probabilidade de um partido permanecer na coalizão diminui à medida que o mandato presidencial chega ao fim, indicando a existência de ciclos de cooperação entre atores políticos. Verificou ainda que a distribuição de portfólios, popularidade e a distância ideológica poderiam determinar a permanência na coalizão. 
essas ações, a governante esperava aumentar sua capacidade de coordenação da maioria para ter maior eficácia político-operacional. Entretanto, em meio à grave crise política e econômica em contexto de baixa popularidade da presidente e da classe política, ameaçada por denúncias de corrupção pela operação Lava Jato, seu governo foi seriamente afetado desde o início de 2015.

Em outubro desse mesmo ano, a presidente promoveu uma reforma ministerial. O principal objetivo dessa reforma foi assegurar a governabilidade, com a formação de uma nova base de apoio partidário no Congresso, a fim de o governo obter maioria parlamentar, evitar as derrotas que vinha sofrendo e conseguir a aprovação das matérias de seu interesse na Câmara e no Senado. Como podemos ver na tabela 2, Rousseff reduziu o seu ministério, passando de 39 pastas para 31, ampliou o espaço do РмDв (segundo maior partido da coalizão), que passou de seis para sete Ministérios, diminuiu o poder do PT, reduzindo as pastas do partido de 13 para 9. Observa-se, ainda, a entrada do Рт в no Ministério, e a saída do pros da pasta dos Esportes, redundando no aumento da maioria na Câmara, mas manteve o mesmo número de partidos da coalizão, conforme tabela 3. Na oposição ao seu governo permaneceram partidos de centro-direita e direita (PSDB, DEM, SD, PSC), centro-esquerda (PSB, PPS, PV) e esquerda (PSOL), além de outros partidos menores.

O governo de Rousseff passaria ainda por grave alteração em março de 2016 com a saída do PMDB de seu Ministério após os conflitos entre as duas forças políticas se ampliarem, conforme tabela 2. Apesar do desembarque peemedebista, Temer continuaria na Vice-Presidência da República sob o argumento de que teria sido eleito pela população na chapa de Dilma e de que não ocuparia, portanto, cargo de submissão à presidente.

A decisão do PMDB influenciaria outros partidos da base aliada que acabaram saindo do governo à medida que o processo de impeachment foi avançando, resultando no aumento dos ministérios apartidários, chegando a 48,4\%. Ademais, apesar da entrega de cargos, a ala do PMDB descontente com o governo ganhou força com a queda continuada de popularidade da presidente, agravada pela paulatina gama de denúncias relacionadas à operação Lava Jato.

\section{A insustentável força de Executivos reféns de Legislativos em Sistema Presidencialista: Composição Partidária e Proporcionalidade das Coalizões Legislativas de Collor e Rousseff}

No que se refere à base de apoio da coalizão na Câmara dos Deputados, verificamos, na tabela 3, que, no governo Collor, o comportamento dos partidos foi no sentido do distanciamento do Executivo, o que resultou em coalizões minoritárias durante todo o seu mandato, dificultando a governabilidade e 
tabela 2 Distribuição de Ministérios por partido da Coalizão do Governo Dilma (2015-16)

\begin{tabular}{|c|c|c|c|c|c|}
\hline & & \multicolumn{2}{|c|}{ Ministérios } & \multicolumn{2}{|c|}{$\begin{array}{c}\text { \% de cadeiras na Câmara dos } \\
\text { Deputados }\end{array}$} \\
\hline & & $\mathbf{N}$ & $\%$ & Partido da Presidente & Coalizão \\
\hline \multirow[t]{13}{*}{ Dilma I } & $\mathrm{PT}$ & 13 & 33,3 & 13,3 & 59,2 \\
\hline & PMDB & 6 & 15,3 & & \\
\hline & PSD & 2 & 5,1 & & \\
\hline & PDT & 1 & 2,5 & & \\
\hline & PCdoB & 1 & 2,5 & & \\
\hline & PP & 1 & 2,5 & & \\
\hline & PR & 1 & 2,5 & & \\
\hline & PROS & 1 & 2,5 & & \\
\hline & Ртв & 1 & 2,5 & & \\
\hline & PRB & 1 & 2,5 & & \\
\hline & Sem filiação & 11 & 28,2 & & \\
\hline & partidária & & & & \\
\hline & Total & 39 & & & \\
\hline \multirow[t]{11}{*}{ Dilma II } & PT & 9 & 29 & 13,3 & 61,9 \\
\hline & РMDB & 7 & 22,5 & & \\
\hline & PSD & 1 & 3,2 & & \\
\hline & PDT & 1 & 3,2 & & \\
\hline & PCdoB & 1 & 3,2 & & \\
\hline & PP & 1 & 3,2 & & \\
\hline & $\mathrm{PR}$ & 1 & 3,2 & & \\
\hline & Ртв & 1 & 3,2 & & \\
\hline & PRB & 1 & 3,2 & & \\
\hline & $\begin{array}{l}\text { Sem filiação } \\
\text { partidária }\end{array}$ & 8 & 25,8 & & \\
\hline & Total & 31 & & & \\
\hline \multirow[t]{5}{*}{ Dilma III } & $\mathrm{PT}$ & 9 & 29 & 11,3 & 42,1 \\
\hline & PCdoB & 2 & 6,8 & & \\
\hline & PDT & 1 & 3,2 & & \\
\hline & PROS & 1 & 3,2 & & \\
\hline & PP & 1 & 3,2 & & \\
\hline
\end{tabular}


TABEla 2 Distribuição de Ministérios por partido da Coalizão do Governo Dilma (cont.)

\begin{tabular}{lcccc}
\hline & Ministérios & $\begin{array}{r}\text { \% de cadeiras na Câmara dos } \\
\text { Deputados }\end{array}$ \\
& N & $\%$ & Partido da Presidente Coalizão \\
& 1 & 3,2 & \\
PR & 1 & 3,2 & \\
PSD & & & \\
Sem filiação & 15 & 48,4 & \\
partidária & 31 & & \\
Total & &
\end{tabular}

Fonte: Organizada pela autora com dados do Tribunal Superior Eleitoral (TSE).

garantido a formação de uma folgada maioria no Legislativo pelos partidos da oposição visando o seu impedimento. Esse desfecho ocorreu num contexto marcado pela crescente perda de credibilidade do ex-presidente e de desgaste progressivo de seu governo em decorrência do insucesso de sua política econômica e das frequentes denúncias de corrupção envolvendo seus auxiliares diretos (incluída a primeira-dama Rosane Malta, presidente da Legião Brasileira de Assistência).

É importante salientar que a primeira crise do governo Collor se iniciou ainda em junho de 1991, quando veio a público disputa envolvendo seu irmão, Pedro Collor, e o ex-tesoureiro da campanha eleitoral de Collor de Mello, o empresário Paulo César Farias, em torno da aquisição do jornal Tribuna de Alagoas. Com esse empreendimento, PC Farias visava construir uma rede de comunicação que rivalizasse com a Gazeta de Alagoas e as Organizações de Arnon de Mello (pai do ex-presidente Collor). Essa crise teve novos contornos no ano seguinte com outras acusações do irmão do ex-presidente alagoano sobre a origem do enriquecimento do empresário PC Farias às custas de sua amizade com o presidente.

Finalmente, em maio de 1992, o chamado "esquema PC" veio à tona. Por meio desse esquema, Pedro Collor acusava PC Farias de operar uma extensa rede de corrupção e tráfico de influência na qualidade de "testa-de-ferro" do presidente Collor, o qual seria um dos beneficiários diretos. A partir daí, a Polícia Federal abriu um inquérito destinado a apurar as denúncias de Pedro Collor e o Congresso Nacional instaurou uma Comissão Parlamentar de Inquérito (CPI) destinada a investigar a veracidade das acusações. Essa CPI foi presidida pelo deputado Benito Gama (PFL-BA) e o senador Amir Lando 
(PMDB-RO) foi o relator. Outro fator decisivo para que as investigações dessa CPI avançassem foi a participação da sociedade civil organizada, especialmente das manifestações de jovens estudantes denominados caras-pintadas, e de meios de comunicação ${ }^{25}$.

O pedido de abertura do processo de impeachment foi aprovado em 29 de setembro de 1992 por vasta maioria dos parlamentares. Foram 441 votos a favor e 38 votos contra, com uma abstenção e 23 ausências, demonstrando assim o total isolamento do presidente. Não contou nem com todos os votos de seu próprio partido, o PRN, nem do principal partido aliado, o $\mathrm{PFL}^{26}$.

Afastado da presidência da República em 2 de outubro, foi julgado pelo Senado Federal em 29 de dezembro de 1992, sendo condenado à perda do cargo, ficando inelegível politicamente por oito anos pelo placar de 76 votos a 5. Como último recurso para preservar seus direitos políticos, Collor renunciou ao mandato antes do início do julgamento, mas a sessão teve continuidade. Collor foi sucedido pelo vice-presidente, Itamar Franco, que exercia o cargo interinamente desde seu afastamento, em 2 de outubro.

Já no governo Rousseff, conforme informações da tabela 3, embora seu partido se mantivesse com representação minoritária, a coalizão atingiu ampla maioria no Legislativo no primeiro ano do seu segundo governo, resultando em um ministério bem montado, sob o ponto de vista da divisão de poder entre o PT e as legendas aliadas, das quais dependeria de apoio no Congresso. Mas já em março de 2016, com a saída do PMDв е de outros partidos da base de apoio no Legislativo, esse cenário mudaria radicalmente. Ainda em fins de março sairia o PRB, e em meados de abril, o PP. Sem esses partidos, e as demais legendas formadoras do Centrão, a ex-presidente passou a contar com uma coalizão minoritária no Legislativo, perdendo o apoio partidário necessário

25 Em agosto de 1992, o relatório final da "CPI do PC Farias" foi aprovado. Neste documento, o presidente da República e seus familiares foram acusados de terem despesas pessoais pagas pelo dinheiro recolhido ilegalmente pelo "esquema PC". Por tal esquema, haveria a distribuição de tais recursos por meio de uma intrincada rede de "laranjas" e de "contas fantasmas". Entre outros favorecimentos foram citadas a reforma na "Casa da Dinda" (residência de Fernando Collor em Brasília) e a compra de um automóvel Fiat Elba. A partir dessas provas, um pedido de impeachment foi formulado tendo como signatários o jornalista Barbosa Lima Sobrinho, presidente da Associação Brasileira de Imprensa, e o advogado Marcelo Lavenére, presidente da Ordem dos Advogados do Brasil.

26 O instinto de sobrevivência da classe política perdurou tendo em vista a proximidade das eleições municipais de 1992 e o desejo de reeleição em 1994, levando muitos parlamentares a optarem pelo "sim" no momento decisivo, apesar de promessas em sentido contrário. Este foi o caso do deputado Onaireves Moura (do Ртв do Paraná), que dias antes organizara um jantar de desagravo ao presidente e a seguir o voto do alagoano Cleto Falcão, ex-líder do PRN na Câmara e amigo íntimo de Collor. 
tabela 3 Composição Partidária e Proporcionalidade das Coalizões de governo - Collor e Rousseff

\begin{tabular}{|c|c|c|c|c|c|c|}
\hline \multirow[t]{2}{*}{ Coalizão } & \multirow[t]{2}{*}{$\begin{array}{l}\text { Partido do } \\
\text { presidente }\end{array}$} & \multirow[t]{2}{*}{$\begin{array}{l}\text { Partidos na } \\
\text { Coalizão }\end{array}$} & \multirow[b]{2}{*}{ Início } & \multirow[b]{2}{*}{ Fim } & \multicolumn{2}{|c|}{$\begin{array}{c}\text { \% de cadeiras na } \\
\text { Câmara Deputados }\end{array}$} \\
\hline & & & & & $\begin{array}{l}\text { Partido do } \\
\text { Presidente }\end{array}$ & Coalizão \\
\hline Collor 1 & PRN & PRN-PFL & $15 / 03 / 90$ & $12 / 10 / 90$ & 5,1 & 33,94 \\
\hline Collor 2 & PRN & PRN-PFL-PDS & $13 / 10 / 90$ & $31 / 01 / 91$ & 6,1 & \\
\hline Collor 3 & PRN & PRN-PFL-PDS & $01 / 02 / 91$ & $14 / 04 / 92$ & 8,0 & 34,59 \\
\hline Collor 4 & PRN & PRN-PFL-PDS-PTB-PL & $15 / 04 / 92$ & $30 / 09 / 92$ & 6,2 & 43,54 \\
\hline Dilma 1 & PT & $\begin{array}{l}\text { PMDB-PDT-PCdoB- } \\
\text { PROS-PP-PR- } \\
\text { PSD-PRB }\end{array}$ & $01 / 01 / 15$ & $01 / 10 / 15$ & 13,6 & 59,2 \\
\hline Dilma 2 & PT & $\begin{array}{l}\text { PMDB-PTB-PR-PRB- } \\
\text { PP-PSD-PROS-PDT- } \\
\text { PCdoB }\end{array}$ & $02 / 10 / 15$ & $29 / 03 / 2016$ & 13,6 & 61,9 \\
\hline Dilma 3 & PT & $\begin{array}{c}\text { PTB-PROS-PSD-PDT- } \\
\text { PCdoB }\end{array}$ & $29 / 03 / 2016$ & $30 / 08 / 16$ & 11,3 & 42,1 \\
\hline
\end{tabular}

Fonte: Dados do Governo Collor em Figueiredo, A. 2007, "Coalition government in the Brazilian democracy", Brazilian Political Science Review, 1 (2): 169 e dados governo Rousseff no Tribunal Superior Eleitoral (TSE).

para salvar o seu governo. Esse quadro se agravaria ainda mais com a migração de onze deputados petistas, passando dos 68 parlamentares eleitos em 2014 para $57 \mathrm{em}$ abril de 2016.

O comportamento do $\mathrm{PMDB}$, diga-se, das ações de suas principais lideranças, entre as quais, o presidente da Câmara dos Deputados, o deputado federal Eduardo Cunha, e o vice-presidente da República, Michel Temer, foi decisivo para entendermos o resultado final do processo que levou ao impeachment. Neste sentido, é importante salientar que a relação do PMDB com o governo da petista foi tensa desde o primeiro mandato. Em virtude desses conflitos, o partido rachou no apoio à reeleição de Rousseff. Ainda em junho de 2014, a manutenção da aliança foi aprovada pela convenção nacional do PMDB, mas recebeu $40,8 \%$ de votos contrários. A ala dissidente reclamava que o partido não era ouvido pelo governo federal e que os ministros da legenda não tinham real poder de comando. 
Ao longo do primeiro ano do segundo mandato de Dilma, a crise se agravou. O primeiro desentendimento entre PT е РMDв ocorreu na disputa pela presidência da Câmara dos Deputados, quando o governo de Rousseff iniciou uma campanha ostensiva para que o deputado Arlindo Chinaglia (PT-SP) vencesse a eleição e derrotasse o deputado Eduardo Cunha (PMDB-RJ). Mas Cunha se elegeu em primeiro turno por grande margem de votos (267 a 136) o candidato do Palácio do Planalto, tornando-se um dos principais inimigos do governo e artífice do impeachment. Um fator que colaborou para chegar a essa situação foi o fato de o PT também ter ficado sem nenhum cargo na Mesa Diretora, por conta da negociação pelo apoio do PR e PSD ao candidato petista na disputa pela presidência da Câmara, quando também perdeu o comando de comissões importantes, como a cobiçada Comissão de Constituição e Justiça (CCJ).

Sob o comando de Cunha, como vimos anteriormente, a Câmara derrotou o Planalto em diversas ocasiões, com a votação de matérias desfavoráveis ao governo. Além disso, houve ainda na Câmara a instalação da CPI da Petrobras para investigar o escândalo de corrupção na estatal, cujos desdobramentos implicariam lideranças petistas e vários políticos oriundos dos partidos da base governamental, mas também da oposição. Logo em seguida, no Senado, Rousseff teve outra derrota desfavorável ao seu governo, quando medidas de ajuste fiscal foram barradas pelo presidente daquela Casa, o peemedebista Renan Calheiros. $\mathrm{O}$ fato de ambos os presidentes das Casas Congressuais, tanto Cunha quanto Calheiros, estarem sendo investigados na operação Lava Jato pioraria ainda mais o clima entre eles e Rousseff. Aos poucos o governo foi ficando refém do Legislativo, reduzindo cada vez mais sua margem de manobra, redundando na paralisia decisória que levou ao impeachment.

O processo de impeachment da ex-presidente Dilma Rousseff iniciou-se com a aceitação, em dezembro de 2015, pelo presidente da Câmara dos Deputados, Eduardo Cunha, de denúncia por crime de responsabilidade fiscal, encerrando-se em agosto de 2016. É importante considerarmos que esse processo ocorreu em meio a várias controvérsias e forte polarização política da sociedade. No âmbito das denúncias, a ex-presidente, ao mesmo tempo que foi acusada de desrespeito à lei orçamentária e à lei de improbidade administrativa, foi alvo de suspeitas de seu envolvimento em atos de corrupção na Petrobras, objeto de investigação no âmbito da operação Lava Jato. Mas também havia juristas que contestavam essas denúncias, com o argumento de que as chamadas pedaladas fiscais não caracterizariam improbidade administrativa e que não existiria qualquer prova de envolvimento da presidente em crime doloso que justificasse o impedimento de seu governo. Enquanto isso, a sociedade brasileira foi às ruas realizando, durante todo o processo, grandes manifestações de rua a favor e contra o impeachment. 


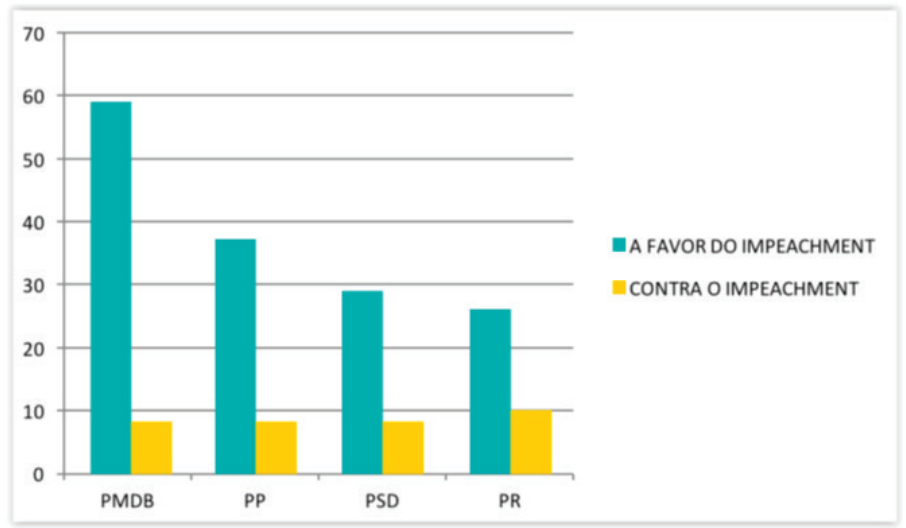

GRÁfICO 1 Votação do PMDB e partidos do Centrão no impeachment da presidente Dilma

FONTE: HTTP://WWW.POLITIZE.COM.BR/PRESIDENCIALIS MO-DE-COALIZAO-E-ATUAL-CRISE-BRASILEIRA

Na Câmara, o relatório da comissão especial de admissibilidade foi favorável ao impedimento da presidente Dilma: 38 deputados aprovaram o relatório e 27 se manifestaram contrários. Em abril de 2016, o plenário da Câmara dos Deputados aprovou o relatório com 367 votos favoráveis e 137 contrários. No Senado, que também formou a sua comissão especial, o relatório foi aprovado por 15 votos favoráveis e 5 contrários. E, em maio daquele ano, o Senado aprovou por 55 votos a 22 a abertura do processo, afastando Dilma da presidência até que o processo fosse concluído. Neste momento, o vice-presidente Michel Temer assumiu interinamente o cargo de presidente. Em 31 de agosto de 2016, Dilma Rousseff perdeu o cargo de Presidente da República após três meses de tramitação do processo iniciado no Senado, que culminou com uma votação em plenário resultando em 61 votos a favor e 20 contra o impedimento. $\mathrm{O}$ principal argumento que levou ao impeachment foi a alegada continuidade, em 2015, da prática das pedaladas fiscais pelo Executivo, que, ao contrariar a Lei de Responsabilidade Fiscal tipificaria uma ação de improbidade administrativa. Houve uma segunda votação para decidir se Dilma deveria perder seus direitos políticos, com placar de 42 votos favoráveis e 36 desfavoráveis. Como houve três abstenções e seriam necessários 54 votos a favor, consequentemente ela não perdeu os direitos e ainda poderia se candidatar a cargos públicos ${ }^{27}$.

27 Informações do site G1 retiradas no dia 24/og/2017 (Garcia e al. 2016). 
Como podemos ver no gráfico abaixo, a maioria dos parlamentares do PMDB e dos maiores partidos do Centrão, antes em sua base de apoio, votou a favor do seu impedimento. Essa perda de apoio, que já vinha ocorrendo durante todo seu segundo governo, foi um dos principais pilares da crise política, resultando no seu impeachment. À medida que o governo foi perdendo sustentação de sua base no Legislativo chefiado por Cunha, sua capacidade de governar caiu significativamente, fazendo com que a aprovação de leis de interesse do governo bem como a execução de políticas públicas fossem severamente prejudicadas, diminuindo drasticamente a popularidade da presidente ao mesmo tempo que aumentava o apoio de vários grupos políticos, dos meios de comunicação e de setores do Poder Judiciário ao impedimento do Executivo.

O sistema presidencialista de coalizão brasileiro passou por graves crises de governança nesta vi República Democrática, cujo desfecho foi o impedimento dos respectivos chefes do Executivo. A instabilidade governamental neste tipo de sistema, observada em outros países latino-americanos, tem entre os fatores em comum uma forte crise econômica, escândalos de corrupção do núcleo do governo, indignação popular e falta de apoio legislativo. Visando colaborar com essa literatura, mas também aprofundar as análises sobre o caso brasileiro, o objetivo deste artigo foi, justamente, analisar o comportamento dos partidos políticos nos dois processos de interrupção dos mandatos presidenciais de Collor e Rousseff, buscando averiguar quais teriam sido as razões para esse abandono da base de apoio partidário.

A partir dos principais pressupostos da escolha racional, verificamos que nos dois eventos comparados, os políticos filiados a partidos, até então aliados ao governo, tomaram decisões visando sua sobrevivência política. Mas, enquanto no caso de Collor a influência das pressões eleitorais e sociais prevaleceram (tendo em vista o comportamento apartidário do próprio presidente desde a campanha eleitoral e a proximidade das eleições municipais de 1992), no caso de Rousseff o fator primordial foi a perda da capacidade do governo de oferecer alternativas de proteção à elite política contra a operação Lava Jato. Isso porque, como vimos, a falta de apoio do Legislativo à presidente no processo de impeachment não decorreu de sua performance na formação da coalizão nas casas congressuais. Pressionada pela crise econômica e reeleita na disputa ao Planalto mais apertada da história política brasileira, a presidente Dilma Rousseff tratou de se fortalecer no Congresso, ainda que em detrimento de seu 
próprio partido. Para isso, ela montou um ministério com a menor proporção de ministros petistas, $34,2 \%$, desde que o partido chegou ao poder federal, incluindo mais ministros de partidos aliados (15) do que os do PT (13), redundando em equipe ministerial mais equilibrada quanto à divisão de pastas de acordo com o peso dos partidos na Câmara. Dilma ainda cedeu pastas que o PT havia sempre controlado, três das quais emblemáticas: Fazenda e Planejamento, para os ministros de perfil técnico, Joaquim Levy e Nelson Barbosa, respectivamente, e Educação para o ex-governador do Ceará, Cid Gomes, do Pros.

Logo, se a principal dificuldade de Collor foi atrair apoios de partidos suficientes para formar a maioria necessária para mantê-lo no governo, no caso de Rousseff o maior problema foi manter a maioria parlamentar inicial devido às ameaças da Operação Lava Jato à maioria da elite política e à ausência de vínculos mais duradouros entre os partidos da base e a própria presidente capazes de sustentar uma coalizão com um partido fisiológico, como о Рм Dв (mesmo sendo o principal partido aliado, legenda típica de centro-direita, com muitas facções e com uma bancada de tamanho considerável com extensa capilaridade eleitoral em nível territorial, mas que internamente não tinha unanimidade em relação ao governo e com o qual o PT manteve uma relação tensa desde o primeiro governo de Rousseff). O PMD B, ao passar para oposição, apresentando uma agenda parlamentar própria e, mais adiante, um novo governo capaz de proteger políticos das punições da operação Lava Jato, fortaleceu ainda mais esse campo político, atraindo outros partidos da base do governo Rousseff. Ao agregar outros partidos da oposição, como o PSDB e o DEM, esses partidos inverteram a correlação de forças entre o Executivo e o Legislativo, tornando o primeiro refém do segundo, com ampla maioria no Congresso.

Os dois casos de impeachment estudados revelam que os partidos e o sistema partidário são fundamentais para o presidencialismo de coalizão funcionar adequadamente. Mas para isso as coalizões precisam ser formadas em torno de questões programáticas que representem as demandas dos setores sociais canalizadas pelos partidos políticos para a arena Legislativa. Enquanto predominarem coalizões baseadas apenas na distribuição de cargos e outros recursos de poder aos partidos políticos, a tendência é ficarmos mais distante de um Estado de Direitos. E aí pode estar o principal ponto positivo desse arranjo, ou seja, a constante necessidade de coordenação política entre poderes e a possibilidade de um contrato suprapartidário, mas em benefício da sociedade. Em outras palavras, por meio do presidencialismo de coalizão é possível haver a união de diversos partidos em prol de uma agenda de governo que possa convergir para dar maior equilíbrio à diversidade de demandas sociais de um país tão desigual como o Brasil. 


\section{Referências bibliográficas}

Abranches, S. 1988, "Presidencialismo de coalizão: o dilema institucional brasileiro", Dados, 31 (1): 5-38.

Amaral, O. 2010, As transformações na organização do Partido dos Trabalhadores entre 1995 e 2009, tese de doutorado em Ciência Política, Campinas, IFCH, Unicamp.

Bardi, L. \& Mair, P. 2008, “The parameters of party systems", Party Politics, 14 (2): 25-61.

Bohn, S. \& Paiva, D. 2007, "Sistema Partidário de Volatilidade Eleitoral no Brasil: um estudo sobre a dinâmica inter-regional", trabalho apresentado no $37^{\circ}$ Encontro Anual daANPOCS.

Braga, M. do Socorro Sousa 2016a, "As eleições brasileiras de 2014: balanço dos resultados e implicações político-institucionais", Política \& Sociedade: Revista de Sociologia Política, 15 (32): 39-64.

Braga, M. do Socorro Sousa 2016b, "A Política no Nordeste: Oligarquia, Partidos e Movimentos Sociais", in Â. Nascimento \& M. Costa Lima eds., O Nordeste Brasileiro em questão: uma agenda para reflexão. 1ed. Recife: Editora Sudene, v. 2: 79-127.

Braga, M. do Socorro Sousa 2010, "Eleições e democracia no Brasil: a caminho de partidos e sistema partidário institucionalizados", Revista Brasileira de Ciência Política, 4: 43-72.

Braga, M. do Socorro Sousa 2006, O processo partidário-eleitoral brasileiro: padrões de competição política (1982-2002), São Paulo, Humanitas/FAPESP.

Dalton, R. J., Macallister I. \& Wattenberg M. 2000, "The Consequences of Partisan Dealignment", in R. J. Dalton y M. P. Wattenberg eds., Parties without Partisans: Political Change in Advanced Industrial Democracies, New York, Oxford University Press.

Figuereido, A. \& Limongi F. 1998, "Bases institucionais do presidencialismo de coalizão", Lua Nova, 44: 81-106.

Figuereido, A. \& Limongi F. 2007, "Coalition government in the Brazilian democracy", Brazilian Political Science Review, 1 (2):182-216.

Kinza, M. D’Alva 1993, Radiografia do quadro partidário brasileiro, São Paulo, Fundação Konrad Adenauer Stiftung.

Limongi, F. 2017, "Impedindo Dilma”, Novos Estudos Cebrap: 5-13.

Linz, J. J. et al. 1991, A opção parlamentarista, IDESP/Sumaré.

Mainwaring, S. 1993, "Presidentialism, multipartism, and democracy: The difficult combination", Comparative political studies, 26 (2): 198-228.

Marques, J. R. \& Fleischer, D. V. 1998, De facção a partido. O Partido da Social Democracia Brasileira (PSDB) (1987/1995), Brasília, Konrad Adenauer Stiftung.

Meneguello, R. 1989, PT: a formação de um partido (1979-1982), Rio de Janeiro, Paz \& Terra. 
Meneguello, R. \& Amaral, O. 2008, "Ainda novidade: uma revisão das transformações do Partido dos Trabalhadores no Brasil", BSP Occasional Papers, 2: 1-25.

Müller, W. \& Strøm, K. eds. 2000, Coalition governments in Western Europe, London, Oxford University Press.

Neto, O. A. 2000, "Presidential cabinets, electoral cycles, and coalition discipline in Brazil", Dados, 43 (3): 479-519.

Neto, O. A. 2006, Presidencialismo e governabilidade nas Américas, Rio de Janeiro. FGV Editora.

Nicolau, J. M. 1998, Dados Eleitorais do Brasil (1982-1996), Rio de Janeiro, Editora Revan/ FGV.

Pereira, C. \& Mueller, B. 2003, "Partidos fracos na arena eleitoral e partidos fortes na arena legislativa: a conexão eleitoral no Brasil", Dados, 46 (4): 735-771.

Pérez-Liñan, A. 2007, Presidential Impeachment and the new political instability in Latin America, New York, Cambridge University Press.

Ribeiro, P. F. 2008, Dos sindicatos ao governo: a organização nacional do PT de 1980 $a$ 2005, tese de doutorado em Ciência Política, São Carlos, Centro de Educação e Ciências Humanas, UFSCar.

Roma, C. 2002, "A institucionalização do PSDB entre 1988 e 1999", RBCS - Revista Brasileira de Ciências Sociais, 17 (49): 71-92.

Sallum Jr., B. 2015, O Impeachment de Fernando Collor: Sociologia de uma crise, São Paulo, Editora 34 .

Sallum Jr., B. \& Casarões, G. Stolle Paixão 2011, “O Impeachment do Presidente Collor: a literatura e o processo", Lua Nova, 82: 163-200.

\section{Artigos de imprensa}

Braga I., Lima M. e Gama J. 2015, "Eduardo Cunha derrota o governo e é eleito presidente da Câmara", O Globo, consultado em 7/o6/2018, https://oglobo.globo.com/ brasil/eduardo-cunha-derrota-governo-e-eleito-presidente-da-camara-15214504\#ixzz4tbopnW1A.

Garcia G. e al. 2016, "Senado aprova impeachment, Dilma perde mandato e Temer assume”, O Globo, consultado em 7/o6/2018, http://g1.globo.com/politica/processo-de-impeachment-de-dilma/noticia/2016/o8/senado-aprova-impeachment-dilma-perde-mandato-e-temer-assume.html.

Este artigo insere-se no âmbito de projeto de pesquisa "Avaliando a qualidade da democracia em países da América Latina (II)", apoiado com bolsa de produtividade pelo Conselho Nacional de Desenvolvimento Científico e Tecnológico (CNPq).

$\mathrm{O}$ autor agradece a leitura atenta, as valiosas sugestões e as críticas dos pareceristas da Revista Lusotopie. 